Religious Studies 38, 471-487 (C) 2002 Cambridge University Press

DOI: $10.1017 /$ S0034412502006121 Printed in the United Kingdom

\title{
Faith as doxastic venture
}

\author{
J OH N BISHOP \\ Department of Philosophy, University of Auckland, Auckland, New Zealand
}

\begin{abstract}
A 'doxastic venture' model of faith - according to which having faith involves believing beyond what is rationally justifiable - can be defended only on condition that such venturesome believing is both possible and ethically acceptable. I show how a development of the position argued by William James in 'The will to believe' can succeed in meeting these conditions. A Jamesian defence of doxastic venture is, however, open to the objection that decision theory teaches us that there can be no circumstances in which 'the evidence does not decide', so a fortiori no occasion to permit belief on a 'passional' basis. I argue that this objection does not apply to certain 'framework principles' such as those presupposed by the framework of theistic belief and practice, and that there are good grounds for preferring a doxastic venture model of faith over a more austere alternative (advocated by Richard Swinburne) according to which reasonable faith cannot be more than the commitment to act on the assumption, with any (non-negligible) degree of confidence, that God exists and is to be trusted.
\end{abstract}

What is faith? And can it be justifiable to 'have faith', in the sense in which Christians 'have faith'?

In this paper I shall consider the prospects for defending a 'doxastic venture' model of faith. There are, of course, various conceptions of faith. The conception with which I am here concerned can be specified initially as meeting two desiderata. First, under the intended conception, someone who has Christian faith is to be understood as exercising, with respect to Christianity, a capacity which could be exercised differently - with respect to the beliefs and practices of a different religion, or, maybe, with respect to beliefs and practices not normally regarded as 'religious' at all. Kierkegaard's definition of faith as 'an objective uncertainty held fast in an appropriation process of the most passionate inwardness' ${ }^{\prime}$ is a definition that meets this first desideratum. My second desideratum is also Kierkegaardian: under the intended conception, faith essentially involves active risk or venture - as is popularly said, a 'leap of faith'.'

The doxastic venture model is a model of faith under the intended conception. According to this model, faith involves beliefs which are held 'by faith', in the sense 
that holding them is an active venture which goes beyond - or even, perhaps, against - what can be established rationally on the basis of evidence and argument. The venture of faith is, or includes, doxastic venture.

By contrast, though within the same broad conception of faith as defined by my two desiderata, a 'fiducial venture' model of faith rejects the idea that faith involves venturesome believing. On such a model, the belief component of faith is, like all belief, a matter of holding true what the evidence shows to be true. The venture of faith is an act of trust, or of entrusting oneself, in the light of what is believed. Scripture says that 'the devils also believe, and shudder' (James 2.19). Belief that God exists is therefore not sufficient for faith - or, at least, not meritorious Christian faith. What is also required is appropriate commitment to God, and making that commitment is making the venture of (theistic) faith. ${ }^{3}$

A fiducial venture model seems to have at least one important advantage over the doxastic venture model. Because it does not endorse believing beyond what the evidence warrants, it apparently offers better prospects for reconciling faith with reason. And I shall take it as a third and further desideratum for my intended conception of faith that faith be broadly reasonable in the sense that exercising the capacity for faith should be in harmony with the exercise of our rational capacities.

A disadvantage with a fiducial venture model of faith, however, is that it may have difficulty accounting fully for faith's venturesomeness. If the act of trusting God is based on the belief that God is trustworthy, then, if this belief is itself held only to the extent justified by the evidence, only mundane venture seems involved: faith in God amounts to trusting the trustworthy.

Furthermore, the correct model of faith may have to include doxastic venture. Should all defences of Christian (or, more generally, theistic) belief as justified by evidence turn out to be inherently circular - as is arguable - something like doxastic venture may then be needed to break into the circle. I shall return to this point in the penultimate section below.

I shall not, however, develop further the comparison between a doxastic venture and competing models of faith, because my interest in this paper is solely with the question whether a doxastic venture model can be shown even to be a serious contender for an account of reasonable faith under the intended conception. For, serious doubts may be raised about the viability of the doxastic venture model.

The first doubt is that doxastic venture may seem an impossible feat, since arguably it is impossible to exercise the kind of direct control over beliefs that would seem required for believing 'by faith'. If the possibility of doxastic venture can nevertheless be vindicated, a second, ethical, doubt arises: how could it be morally justifiable to believe beyond or against what is rationally warranted? And a third doubt is linked with the second: if faith under the intended conception has to be broadly reasonable, how can doxastically venturesome faith qualify, if the 
venture takes the believer beyond rational warrant? Doxastic venture can be broadly reasonable only if it is not an absolute requirement on reasonably held belief that one believes only to the extent that belief is rationally warranted on the evidence. But can it be shown that this is not a requirement?

My purpose in this paper, then, is to consider whether these problems for a doxastic venture model of faith can be overcome. I shall argue that they can, and thus that the doxastic venture model is a viable account of reasonable faith under the intended conception.

\section{How doxastic venture is possible}

The first doubt first: do we have some kind of direct voluntary control relating to our beliefs in terms of which it is possible to make coherent sense of the notion of believing by faith beyond what the evidence supports?

I think so. Belief functions to guide action, in the light of desires and intentions. But the concept of an agent acting on a given belief is not just the concept of that belief causing the agent's behaviour, while the agent herself, so to say, stands idly by. In acting on her belief the agent is active. When a person acts on her belief that $p$, there is the state of her holding it true that $p$, and there is also her employing the content ' $p$ ' in her practical reasoning. Her belief-state involves the characteristic 'doxastic feeling' of holding something true, and that is indeed beyond her direct control: she could not simply will not to have this doxastic feeling. However, the practical inference which results in her action is something she does, and it includes her taking account of the content ' $p$ '.

Such doings are typically so straightforward and undeliberate that they pass unnoticed. They are doings none the less. The proper functioning of beliefs does depend on a highly regular - even, in a sense, automatic - transition from being in the state of holding it true that $p$ to employing $p$ in practical inference as soon as the question whether $p$ becomes salient. Yet the fact that these transitions are exercises of the agent's own control is shown by their capacity to be interrupted by the agent. The agent has no (direct) power not to be in a belief-state he is in fact in; but he does have direct power not to take the content of that belief-state to be true in his practical inferences. For example, I may come to recognize that certain of my beliefs have been produced in me through some pathology or prejudice, and so I may refrain from employing their content in my practical reasoning, even though the 'feeling' that they are true (annoyingly) persists.

Some philosophers draw the distinction between belief as an attitudinal state and belief as employed in reasoning as a distinction between belief and 'acceptance'. ${ }^{4}$ Now, of course, one can accept the content that $p$ in one's reasoning without at all believing that $p$. However, if this terminology involves the idea that there is one thing - believing - which is wholly involuntary, and another thing accepting - which is voluntary, it does not carve quite at the joints. When one 
accepts in reasoning what one also believes, the acceptance is not mere acceptance, but, so to say, believing-acceptance. The attitude of the belief state is present in the accepting of what is believed in reasoning. It is preferable, then, to say that believing has both a passive and an active aspect - the belief-state of 'feeling' that a proposition is true, which is not under direct control, and the accepting of what one believes in reasoning, which is under direct control. Though generally disposed to accept in reasoning what we hold true, we control our acceptance and may withhold it. We are also able merely to accept a proposition in reasoning (that is, to 'act as if we believed'), quite independently of finding ourselves to hold it true. But when we believingly accept, what we do is something under our direct control. That is the voluntary aspect of believing.

Does it follow from this account that an act of doxastic venture is possible? Given that acceptance of a propositional content is under our direct control, we do have the ability to accept that $p$ without taking it to be epistemically justified to believe that $p$. But such acceptance, by itself, amounts just to the possibility of acting on the assumption that $p$, and acting on the assumption that $p$ seems to fall short of believing that $p$ by faith. What seems needed for believing by faith is believing-acceptance, not the mere acceptance involved in acting on an assumption. But how could believing-acceptance be possible if what is accepted is recognized as lacking evidential warrant? One can accept in practical reasoning what one recognizes not to be evidentially warranted: but that recognition will surely exclude the possibility of accepting believingly? So the possibility of doxastic venture - of believing by faith - has yet to be made out.

In his famously controversial 1895 lecture, 'The will to believe', William James aims to provide 'a justification of faith, a defence of our right to adopt a believing attitude in religious matters in spite of the fact that our merely logical intellect may not have been coerced'.$^{5}$ I take James to be defending both the possibility and the ethical permissibility of what I have been calling doxastic venture.

James states his thesis thus: 'Our passional nature not only lawfully may, but must, decide an option between propositions, whenever it is a genuine option that cannot by its nature be decided on intellectual grounds'; and immediately adds the following argument for it: 'for to say, under such circumstances, "Do not decide, but leave the question open", is itself a passional decision - just like deciding yes or no - and is attended with the same risk of losing the truth [as deciding no]'. ${ }^{6}$

James's notion of 'our passional nature' settling an option contains a ready solution to the question of how doxastic venture is possible. It is not only our perceptual and rational capacities that generate beliefs. Beliefs may have other origins, which James calls 'passional', using the term as something of a catch-all. Emotions and desires may give rise to beliefs, as also may affections and affiliations - including cultural and religious traditions. Thus, believing-acceptance beyond what we find to be rationally justifiable is entirely possible, provided 
the attitude of holding true required for belief has passional origins. (This account of how doxastic venture is possible incidentally resolves the apparent paradox whereby Christian faith is traditionally regarded both as gift and act. What God gives is the passionally based inclination to hold the Gospel message true - an inclination which then needs to be actively accepted in practical commitment.)

\section{How doxastic venture can be permissible}

Now to the ethical doubt, and the doubt about how doxastic venture could fairly be described as broadly reasonable.

Is it ever morally permissible to let ourselves follow passional inclination by accepting what we recognize not to be epistemically justified? Or should we pull ourselves up short, recognizing that 'it is wrong, always, everywhere, and for anyone, to believe anything upon insufficient evidence' ?

To defend doxastic venture, I believe it is helpful to follow James's answer to this question - though an important amendment will need to be made to his position. James's answer is that we are within our moral rights if we let ourselves believe beyond the evidence on a passional basis - but only if two conditions are satisfied:

(1) The question concerned is one which 'by its nature cannot be decided on intellectual grounds',

and

(2) The question we are settling is a 'genuine option'.

What is a genuine option? An option is, on James's definition, a choice between 'hypotheses', a choice as to what to believe on a given issue. James defines a genuine option as one which is living, forced and momentous.

For an option to be living for a given person, the hypotheses for choice have to be 'live', in the sense that each has, in James's words, to 'make some appeal, however small' to the person's belief. And that entails that the question what to believe on the issue that the competing hypotheses each claims to resolve has to make sense to and have point for the person concerned. So, for example, the option to believe or not to believe that God exists is a living option for me only if each possibility has some appeal to my capacity to give and withhold belief - and that presupposes, of course, that the question whether God exists must be, for me, a question which has point. An option is momentous when it matters significantly which hypothesis the person adopts - where what the person believes on the issue concerned affects significant actions of hers or, more broadly, what kind of a life she leads or person she becomes.

On the notion of a forced option James says,

If I say 'Either love me or hate me' ... your option is avoidable. You may remain indifferent to me, neither loving nor hating ... . But if I say 'Either accept this truth 
or go without it', I put you on a forced option, for there is no standing place outside of the alternative. Every dilemma based on a complete logical disjunction, with no possibility of not choosing, is an option of this forced kind. ${ }^{8}$

But, of course, any issue may be presented in a forced or a non-forced fashion. The question whether $p$ may be presented as 'Am I going to believe that $p$ or not believe that $p$ ?', the forced presentation. Or it may be presented as 'Am I going to believe that $p$ or disbelieve that $p$ (that is, believe that not- $p$ )?', which is not forced, since I may neither believe that $p$ nor disbelieve that $p$. Forcedness is thus a contextually dependent feature of the way an option is presented. The question whether $p$ presents as forced for a person just when what matters to her is the choice between believing that $p$ and not believing that $p$.

Doxastic venture is justifiable, then, according to James, when it settles a genuine option in principle unable to be settled by intellectual assessment of the evidence.

It is important to recognize that James is not condoning all passionally based belief. He gives no comfort to irrationalist fideism - the view that faith requires believing contrary to one's rational assessment of the evidence. When a question is settled by our assessment of the evidence, James agrees that we should believe accordingly. All he is defending is suprarationalist believing by faith, or 'overbelief' ${ }^{\prime}$ - believing on passional grounds beyond, yet still consistently with, what can be established rationally. Thus, contrary to some interpretations, ${ }^{10}$ I take James not to be quarantining religious or other faith-based beliefs from public rational and scientific inquiry. The Jamesian affirmation of the permissibility of doxastic venture under the stated conditions regards such venturing as needing to be broadly in harmony with the proper exercise of our rational features.

\section{Ethical objections to doxastic venture}

I wish to consider two objections - the two most important, I believe - to this Jamesian defence of the ethical permissibility and reasonableness of doxastic venture for resolving genuine options not settleable on intellectual grounds. The first is an ethical objection (or a conjunction of ethical objections); and the second is that the defence ignores what decision theory has to teach us about practical rationality.

It might be maintained that what James is defending is wishful thinking wishful thinking under significant constraints, perhaps, but wishful thinking none the less. And that may seem objectionable. A life based on wishful thinking, while perhaps not necessarily positively immoral, does seem, surely, to be less than morally ideal.

Furthermore, it may be objected that allowing passional resolution of genuine options not decidable on the evidence threatens to open the door to morally obnoxious beliefs. It may, for example, be a living, momentous, and forced option 
for a person whether or not to believe that there is a white-supremacist God, and whether there is such a God may well not be settleable on the evidence. Yet surely it should not turn out that letting oneself hold this belief could be morally permissible?

These ethical objections can, I think, be dealt with by adding a further condition to the Jamesian account of permissible doxastic venture - a condition James himself may have neglected to make explicit because of his focus on obviously noble religious claims to which people are attracted on passional grounds more weighty then mere wishfulness. I suggest adding to James's own explicit conditions the requirement that passionally motivated doxastic venture be permissible only if

(3) The passional motivation which settles the option is itself morally admirable, or, at least, not morally flawed.

It will then need to be shown that this condition can be satisfied, by means of a theory of virtuous passional motivations for doxastic venture. For present purposes I shall simply assume that such a theory can be provided - and that it can be shown that some passional motivations (e.g. any mere wish that a proposition be true) lack the required virtue which others possess (e.g. being moved by encounter with the Christian Gospel).

This additional condition, does, I think, entail that, for ethically sound doxastic venture, the content of what is believingly accepted on passional motivation must itself not be morally excluded - and that deals with cases like that of the person who makes a passional leap of faith in favour of a racist God."

A Jamesian defence of believing by faith, then, can succeed only with the help of a substantive normative ethic which, inter alia, vindicates the virtue of certain passional motivations for belief and gives ' moral clearance' to the content of what is believed by faith. This is a very significant constraint. Indeed, I believe it has radical implications for any defence of Christian faith, since it will exclude having faith in a God who is both omnipotent and morally perfect for anyone who cannot endorse any normative ethic that would support a satisfactory theodicy. ${ }^{12}$ But I shall say no more about this constraint, in order to focus on the 'decisiontheoretic' objection.

\section{The decision-theoretic objection}

I now consider the decision-theoretic objection to James's claim that passionally motivated doxastic venture is permissible under the conditions stated (including the third condition just added). To see the force of this objection, let me sketch what I take to be James's argument for his claim.

When, on a matter of great significance, we are forced to decide in practice what cannot in principle be decided by our rational evaluation of the evidence, what 
could possibly be wrong with letting non-rational inclinations settle the matter for us?

If you insist, with Clifford, that it is always wrong to decide on anything other than rational grounds, then, when the evidence cannot decide, you must require that judgment be suspended. But in the case of a forced option suspending judgment is practically equivalent to not believing. So, you are requiring that, when the evidence does not decide a forced option, one must always refrain from belief.

But, what justifies this requirement? It is not self-evident, nor establishable by inference from self-evident principles. Are you not, then, just expressing a temperamental, passional, tendency of your own? Are you not simply giving higher priority to avoiding error than to grasping as much truth as you can? And what is there to say that this passional tendency is more ethically honourable than the opposite tendency which is prepared to envisage that non-rational parts of our nature might lead us to truths not graspable by the rational part?

So the question whether it is ethically permissible to settle on passional grounds an evidentially undecidable genuine option, seems itself to be an evidentially undecidable genuine option. Does it not follow, then, that those who purport to settle this question in the negative are pragmatically contradicting themselves because they must be settling it on non-rational grounds ... and that, therefore, the question must be settled in the affirmative?

More is needed for a tight argument to emerge from this sketch. Yet it does suffice to show the force of the 'decision-theoretic' objection, which may be stated as follows.

James's argument assumes that, when it matters for action whether $p$ and the evidence is inconclusive, we are nevertheless forced to choose between believing that $p$ and not believing that $p$. But this assumption is mistaken. If I find it uncertain on the evidence whether $p$, I can rationally assign a degree of belief to $p$, by judging how probable $p$ is on the evidence. Then, given my utilities for possible outcomes, I can take that probability into account by calculating the expected utilities of the options open to me, and acting to maximize expected utility.

Decision theory thus shows how actions can be rationally proportioned to inconclusive evidence. So, when epistemic rationality does not settle matters, practical rationality can. Once we see that what matters for action is our degrees of confidence in the salient hypotheses - rather than what we can actually believe concerning them - we see that there are, in fact, no situations in which 'the evidence does not decide'. And thus we have no need to let options be settled by non-rational influences.

\section{Replying to the decision-theoretic objection: 'sub-doxastic' faith?}

This decision-theoretic objection is open to the following reply. The Jamesian defence of ethically permissible doxastic venture applies only to options 
which are evidentially undecidable (condition (1) above). Now, when the very nature of the question whether $p$ ensures that no rational assessment of evidence could ever settle it, it makes no sense to assign a specific degree of confidence in $p$ 's truth in proportion to the evidence. For, any such assignment is an estimate of how the evidence does settle the matter - and one cannot coherently make such an estimate if one accepts that the matter cannot in principle be settled by evidence.

This reply is open to the following response. Just because it is not reasonable to respond to an evidentially undecidable genuine option by acting on an assumption with a specific, point, degree of confidence, it does not follow that acting on an assumption on the basis of a calculation of expected utility will not be reasonable. For, it can be practically rational to act on an assumption where one's degree of confidence is indeterminately distributed over a sub-interval - even a very wide sub-interval - of the unit interval. And this could be so for the case of theistic belief. ${ }^{13}$ Provided a non-negligible degree of confidence can be placed in the theistic hypothesis, practical rationality takes us only as far as acting on the assumption of its truth with that degree of confidence. And there is thus neither call nor excuse for doxastic venture in its favour.

Interestingly, Richard Swinburne has maintained that acting on the assumption that God exists and is to be trusted just is what constitutes reasonable theistic faith. Swinburne says:

... a man $\mathrm{S}$ has faith if he acts on the assumption that there is a God who has the properties which Christians ascribe to him and has provided for men the means of salvation and the prospect of glory, and that he will do for $S$ what he knows that $S$ needs or wants - so long as $\mathrm{S}$ has good purposes. ${ }^{14}$

According to Swinburne, the person of faith need not believe this assumption he need only have some non-negligible degree of confidence in it. So conceived, the act of faith is, Swinburne thinks, practically rational: a person of faith, he says, acts 'on the assumption that there is a God - for unless there is[,] that which is most worthwhile is not to be had'. Swinburne continues,

He prays for his brethren, not necessarily because he believes there is a God who hears his prayers, but because only if there is can the world be set to right. He lives the good life, not necessarily because he believes that God will reward him, but because only if there is a God who will reward him can he find the deep long-term well-being for which he seeks. ${ }^{15}$

The decision-theoretic objection, then, appears to rule out a doxastic venture model of faith, allowing only an attenuated version of it for which the venture of faith is 'sub-doxastic': that is, for which faith is a matter not of overbelief, but, so to say, of 'overassumption' - or, to return to the notion of acceptance employed earlier, of mere acceptance. ${ }^{16}$ 


\section{Doxastic venture appropriate only for 'irreducibly doxastic' options}

But surely such an attenuated sub-doxastic understanding of faith is too weak? Theistic - particularly Christian - faith seems to involve $a$ certain kind of assurance or certitude - an assurance or certitude which may, indeed, need to be carefully distinguished from any epistemic certainty, but which nevertheless involves believing rather than merely assuming that God exists and is to be trusted. If this is a further, fourth, desideratum for an adequate account of faith, then a Jamesian doxastic venture model provides just what is needed, since it understands the gift of faith as a passionally based tendency to believe the religious claim, and the act of venture as an act of believingly accepting it, in the face of the recognition that it cannot be established epistemically. ${ }^{17}$

But can we show doxastic venture to be reasonable, or do we, as our discussion of the decision-theoretic objection suggests, have to settle at best for Swinburne's sub-doxastic venture model of faith - given, that is, that we seek an account of faith as broadly reasonable?

For the Jamesian defence of doxastic venture to go through there need to be not just contexts which present us with evidentially undecidable genuine options, but contexts where, in addition, the option is, shall we say, irreducibly doxastic. That is, doxastic venture can be reasonable only in response to options where what matters cannot be reduced to whether one does or does not act on the assumption that $p$ with some more or less specific degree of confidence, but amounts to a choice whether or not to accept - to accept believingly - what one is passionally motivated to believe.

But are there any such options - options that are genuine, evidentially undecidable and irreducibly doxastic? Here we face the threat of an impasse where one person's modus ponens is another's modus tollens. On the one (modus ponens) side, we may claim that religious traditions (such as the Christian Gospel) do present genuine options for belief (or, strictly, believing-acceptance) which cannot be settled by the evidence, and that it is therefore reasonable to resolve them through passionally based overbelief. But this may be countered by the (modus tollens) claim that, since (as the decision-theoretic objection maintains) the furthest one can go with the Jamesian argument is to defend the reasonableness of overassumption (overbelief remaining unreasonable), no evidentially undecidable genuine options are irreducibly doxastic, and we can at best accept a sub-doxastic model of faith which prescinds from the assurance of belief. ${ }^{18}$

\section{Choice of 'framework principles' as the locus for faith}

To resolve this impasse in favour of a doxastic venture model of faith and a Jamesian defence of its permissibility, it is necessary to show how there can be 
evidentially undecidable irreducibly doxastic genuine options, and, preferably, to cite other examples of such options apart from that posed by the challenge of the Christian Gospel.

This may conveniently be done, I think, by way of resolving a doubt (raised perhaps by the ghost of logical positivism) about how an evidentially undecidable option could present itself as a genuine option in James's sense - and, in particular, as a forced option. How could a question on which evidence in principle cannot decide (assuming, pace the logical positivists, that such a question can indeed be factually meaningful) be anything other than a purely theoretical question on which it would be eminently appropriate to suspend judgment? How could we have to commit ourselves on such a question?

The first step by way of answer is to consider what sorts of questions might count as essentially evidentially undecidable. The notion of a framework principle proves useful here. A framework principle is a claim whose truth is presupposed by a whole system or framework of beliefs and practices, in the way that (to take the salient example) the principle that God exists and is trustworthy is presupposed by the whole framework of beliefs and practices in the theistic religious traditions. Given its pivotal role in securing the very possibility of belief and action within a given framework, it makes no sense to question the truth of a framework principle from within the framework that presupposes it: such questioning may, however, make sense from outside that framework, though a further and wider framework with its own presupposed framework principles may then be needed to provide the context for such questioning.

Frameworks vary considerably in scope. For example, in the natural sciences, as Hilary Putnam observes, framework principles are principles that 'are employed as auxiliaries to make predictions in an overwhelming number of experiments, without themselves being jeopardized by any possible experimental results' - and Putnam gives the physical principle ' $f=m a$ ' as an example. ${ }^{19}$ Natural science as a whole, however, might also be interpreted as a frameworkand, then, arguably, the principle of induction would be one of its framework principles. The laws of classical logic are framework principles. ${ }^{20}$ And basic ethical principles may be similarly understood: the categorical imperative, for example, being a framework principle for Kantian ethical thought and practice. Some principles may undergird frameworks of thought and action so pervasive that their acceptance is, in practice, unavoidable and apparent only to raised philosophical consciousness - for example, the claim that there are other minds, or that there is a mind-independent external reality. ${ }^{21}$

Any question whether to accept a given framework principle, $p$, then, is such that the question whether $p$ cannot of its very nature be settled by assessing evidence within the context of the framework that presupposes $p$. Now, arguably, the question about the truth of some framework principles is such that, not only can it not be settled evidentially from within the relevant framework, but it 
cannot be settled by any rational assessment of evidence at all. How could this transpire?

A framework principle could be so fundamental - and the framework presupposing it so all-pervasive - that there can be no wider context within which a rational assessment of its truth can take place. Any attempt to provide rational grounds for the principle's truth would necessarily be circular, because the attempt would have to be made within the all-pervasive context that already presupposes the principle's truth. Arguably, the claims that there are other minds and an external world are cases in point. And, certainly, if there are principles presupposed by all rational belief assessment, then those principles will be cases in point. ${ }^{22}$ With such fundamental framework principles, however, we have no real choice about whether or not we believingly accept them. Our acceptance of them may count as doxastic venture in the sense that it involves believing-acceptance beyond evidential support, but it is a 'venture' which is normally irresistible - a venture which requires no risk taking on the part of the individual believer, and therefore, in the ordinary sense, no venture at all. ${ }^{23}$

A framework principle could, however, turn out to be altogether evidentially undecidable even though the framework presupposing it is not all-pervasive and may be considered from an accessible external perspective. Arguably, some more limited frameworks suffer from the same circularity problem that affects the all-pervasive frameworks : that is, all attempts to 'ground' - or, for that matter, undermine-their framework principles from an external perspective turn out to presuppose the very assignment of truth-value that they are intended to secure. The claim that this is so with respect to the theistic framework is by no means implausible - though to establish it would, of course, require extended argument. ${ }^{24}$

It may be the case, then, that there are frameworks of belief and practice that do not belong to the standard set accepted by all properly functioning human beings which nevertheless exhibit epistemic circularity such that their presupposed principles cannot be evidentially assessed. And, pace the natural theologians and the natural atheologians alike, it may be the case that the framework principles of (Christian) theism are of this kind. If so, then, by the very fact that they are framework principles (such that their acceptance or non-acceptance is the acceptance or non-acceptance of a whole framework of beliefs and practices), they may well present to the individual an option which is living, momentous and, indeed, forced, since it may matter here and now whether the individual does or does not embrace them, with suspension of judgment practically equivalent to rejection. Thus, granted the assumption that there are limited frameworks that exhibit epistemic circularity, it follows that for the principles, $p$, of some such frameworks, the option whether or not to accept $p$ may be both a Jamesian genuine option and an option that is evidentially undecidable.

But, to continue to press the issue which emerges from considering the 
decision-theoretic objection, why does resolving an option for or against a framework's principles have to be understood as involving belief-as a matter of choosing whether or not to believingly accept those principles? Could such choices not more readily be shown reasonable if understood as choices about what basic assumptions we make about how things are and what is worthwhile, choices which do not require that we actually believe true what we assume? Indeed, there is a more radical, non-cognitivist, possibility: could such choices not be understood as involving a kind of commitment that does not require either believing or assuming any truths at all - at least, not in any sense which implies that truths correspond to, or are made true by, mind-independent reality? (To illustrate these questions with respect to our choice for or against a religious framework principle: why does this choice have to be understood as a choice of what we believingly accept? Could it not be better understood as a choice of what we will merely assume to be true so far as our practice is concerned - or even, more radically, just as a choice of the kinds of practice we will commit ourselves to, independently not only of any beliefs we have but also of any assumptions we make about what is true?)

\section{Vindicating a doxastic venture model of faith}

Unless it can be shown that the resolution of an option with respect to an evidentially undecidable framework principle can reasonably be a matter of deciding whether to (believingly) accept a passional inclination to believe the principle true, a Jamesian defence of doxastic venture will fall short. I shall conclude by arguing that this requirement can be met: reasonable acceptance of an evidentially undecidable framework principle need not reduce to 'mere' acceptance (acting on an assumption), let alone require only some non-cognitive kind of commitment. ${ }^{25}$ Furthermore, the reasonable acceptance of the framework principles of (Christian) theism is a plausible case in point. A vindication of faith as doxastic venture along Jamesian lines is thus in prospect.

If a reasonable choice of a framework principle can be a matter of accepting a belief about reality, then that framework principle will need to be understood in a realist rather than a non-realist fashion. Framework principles - or some of them anyway - will have to count as assertions about mind-independent reality, rather than as having some non-assertoric function, such as being rules or conventions, or expressions (perhaps by way of fictional constructs) of ultimately subjective or intersubjective values and attitudes. Thus a Jamesian defence of doxastic venture requires a realist understanding of (some) framework principles. That constraint needs to be noted - how serious a constraint it is will of course depend on one's views on the realism/anti-realism debate. That debate might, however, fairly be described as presenting a choice between framework principles - indeed, between $m e t a$-framework principles. And perhaps we should take seriously the proposal 
that this choice - as James himself suggests for the case of moral realism anyway $^{26}$ - presents itself as an evidentially undecidable genuine option, fit to be settled by passionally based doxastic venture! If that is so, then, the attempt to settle by metaphysical argument and evidence the issue between realism and nonrealism is misplaced, and there may be potential for a value-based case in favour of realism.

Be that as it may, and assuming a realist understanding of the relevant framework principles, the defence of doxastic venture requires that it be reasonable for the framework principle accepted to be believed rather than merely accepted as an assumption for action. Doxastic venture involves the more contentious overbelief, not the wholly familiar overassumption. Thus, on the doxastic venture model, to have Christian faith is to believingly accept beyond the evidence and on a passional basis that God exists and is trustworthy, and not, pace Swinburne, merely to act on that assumption with some (perhaps) minimal degree of belief. What can be said to persuade us that the richer Jamesian account is to be preferred, and that Swinburne's sub-doxastic model of faith is not adequate?

The position is, I think, that there are no good grounds for regarding the subdoxastic model as displaying faith as more reasonable than it would be on the richer, Jamesian, doxastic venture, model. So far as the reasonableness of 'having faith' is concerned, the two models are on a par: they differ only in their account of the psychological style of faith commitment (for James, a letting oneself believe what one is prompted to believe; for Swinburne, a setting oneself to act on an assumption, independently of one's doxastic feelings). Given their equality with respect to reasonableness, the Jamesian doxastic venture account should be preferred as phenomenologically superior - since (as already observed) it accommodates the general understanding of Christian faith as involving some kind of assurance or certitude. To conclude my case, then, I offer two related considerations to support my claim that there are no good grounds for taking full doxastic venture to be less reasonable than venturing to act on an assumption.

The first consideration elaborates a point already made. I have already argued that, where the question whether $p$ is in principle evidentially undecidable, there is no rational basis for assigning to the assumption that $p$ any one specific degree of confidence rather than another. So, if one does assume $p$ true in practice, one may reasonably do so with any non-negligible degree of purely subjective confidence. A fortiori, therefore, one may reasonably do so, in particular, with a degree of purely subjective confidence near enough to 1 . Thus, once the propriety of overassumption at the level of framework principles is granted, there is nothing to block the propriety of overbelief - though, of course, to achieve overbelief one has to have the appropriate passional resources.

Here is the second consideration. Once it is acknowledged that with evidentially undecidable genuine options 'the evidence' cannot be in the motivational driving seat, the question arises where we can get the motivational resources even to 
assume a given evidentially undecidable framework principle to be true. Given that the evidence does not establish that God exists and is trustworthy, what could motivate us even just to assume for the purposes of action that this claim is true? Is it not clear that passional motivation is as much needed for over-assumption, and that, therefore, the fact that overbelief has to be passionally motivated cannot be taken as grounds for regarding overbelief as somehow tainted with respect to its reasonableness in a manner which does not affect overassumption? Indeed, given that one needs non-rational resources to be able to commit oneself in practice one way or the other on an evidentially undecidable genuine option, is not the gift of a passional tendency to believe more to be prized than the more austere ability merely to assume?

I make no claim to have shown that a doxastic venture model is the only adequate model of reasonable faith in the sense in which Christians 'have faith'. I believe I have shown, however, that the doxastic venture model can overcome a range of objections which have often been thought to preclude it. I have argued that William James's account in 'The will to believe' does provide a good basis for establishing, under specific conditions, both the possibility and the ethical permissibility and broad reasonableness of passional doxastic venture. In particular, though the decision-theoretic objection to the doxastic venture model is a weighty one, there are good prospects for an adequate reply to it.

I therefore conclude that the question whether to accept or not to accept a framework principle that is evidentially undecidable, that is properly given a realist construal, and that presents a person with a Jamesian genuine option may reasonably and ethically be resolved through that person's letting him or herself employ in practical reasoning a passionally motivated belief on the question, provided that the passional motivation is itself morally admirable, or, at least, not morally excluded. Furthermore, the claim that Christian faith amounts to, or involves, permissible doxastic venture of this kind is a viable theory of such faith. It would, however, be a further project to determine whether the doxastic venture model is altogether the best model of Christian faith. ${ }^{27}$

\section{Notes}

1. S. Kierkegaard Concluding Unscientific Postscript, trans. David F. Swenson and Walter Lowrie (Princeton NJ: Princeton University Press, 1968), 180. Kierkegaard presents this first as his definition of 'subjective' truth, but shortly after makes it clear that truth as thus defined 'is an equivalent expression for faith'.

2. There are, of course, understandings of Christian faith that do not fit the 'intended conception' with which, in this paper, I am exclusively concerned. An important example is Calvin's notion of faith as 'a firm and certain knowledge of God's benevolence towards us, founded upon the truth of the freely given promise in Christ, both revealed to our minds and sealed upon our hearts through the Holy Spirit' (John Calvin Institutes, III, ii, 7, 551) - quoted by Alvin Plantinga in his Warranted Christian 
Belief (Oxford: Oxford University Press, 200o), 244. In this work (see especially chs 8 and 9), Plantinga attempts an impressively thorough defence of this Calvinist conception of faith - a conception which ties faith to a particular content and emphasizes the work of the Holy Spirit rather than any 'leap' on the part of the believer. While it is no part of my present project to assess the Calvinist understanding of faith, it is evidently of relevance to such an assessment whether a good case can be made for a model of faith under the competing conception of it with which I am here concerned.

3. A fiducial model of faith has recently been defended by Paul Helm in his Faith with Reason (Oxford: Clarendon Press, 200o), though not under that description. Helm himself describes his view as an 'evidential proportion' understanding of faith, since he takes it as a requirement that the belief components of faith be held in proportion to their evidential support.

4. See L. Jonathan Cohen An Essay on Belief and Acceptance (Oxford: Clarendon Press, 1992).

5. William James The Will to Believe and Other Essays in Popular Philosophy and Human Immortality (New York NY: Dover, 1956), 1-2.

6. Ibid., 11.

7. Quoted by James (ibid., 8), from W. K. Clifford 'The ethics of belief', Contemporary Review, 29 (1877).

8. Ibid., 3 .

9. To use a term James employs elsewhere - e.g. in Pragmatism, where he speaks of 'the various overbeliefs of men, their several faith-ventures'; see William James Pragmatism, F. Bowers (ed.) (Cambridge MA: Harvard University Press, 1975), 144.

10. For example, David A. Hollinger claims that 'in "The will to believe", James was ... held in thrall by a ... highly nonpragmatic strategy for defending religious belief: the assertion of the reality of separate spheres for religious and scientific cognition', 'James, Clifford and the scientific conscience', in Ruth Anna Putnam (ed.) The Cambridge Companion to William James (Cambridge: Cambridge University Press, 1997), 79-80.

11. If, however, one regards it as possible for someone to have a morally admirable passional motive for embracing a morally objectionable belief, a further, fourth, condition will needed to be added to the Jamesian account of ethically sound doxastic venture - namely, the requirement that what is believed be itself in conformity with correct morality. I am indebted to Rae Langton for this point.

12. Such a person will then be able to maintain theistic faith only given a viable alternative to the traditional concept of 'omni-God' as both omnipotent and morally perfect. See my 'Can there be alternative concepts of God?', Nous, 32 (1998), 174-188.

13. I am indebted to Richard Holton for drawing my attention to the importance of this point.

14. Richard Swinburne Faith and Reason (Oxford: Clarendon Press, 1981), 116, my emphasis. I am indebted

to Peter Forrest for drawing to my attention Swinburne's recent restatement of this 'pragmatist' model of faith in his 'Plantinga on warrant', Religious Studies, 37 (2001), 211.

15. Swinburne Faith and Reason, 117.

16. Swinburne's account as stated might appear as if it does presuppose genuinely doxastic venture - but at the level of the belief that the best can eventuate only if God exists, rather than at the level of belief in God itself. Thus, arguably, Swinburne's account avoids the decision-theoretic objection only if it is revised so that the theistic believer acts only on the assumption, rather than the belief, that the best can eventuate only if God exists.

17. Swinburne claims to derive his 'pragmatist' model of faith partially from James, of whom he says in a footnote 'James seems to commend a faith which is a matter of acting-as-if' (Swinburne Faith and Reason, 115). This does not square, however, with James's evident distaste for Pascal's advice to those convinced by his Wager (see 'The will to believe', 6), nor does it fit with the fact that James describes what he defends as 'overbelief' (my emphasis, see n. 10 above).

Given that, as Mark Kaplan shows in his Decision Theory as Philosophy (Cambridge: Cambridge University Press, 1996), believing that $p$ cannot be defined as a matter of having a degree of confidence in $p$ over a certain threshold, we face what Kaplan calls 'the Bayesian challenge' to explain what need we have for the concept of belief. If it is indeed a desideratum that (Christian) faith include assurance, faith provides a context in which this challenge can be met, since the concept of believing will here not be replaceable by the concept of having some degree of confidence in a hypothesis. Of course, the question whether the notion of belief as distinct from 'degrees of belief' can have any epistemic value would still remain. Kaplan's 'assertion view' is offered in resolution of that question. 
18. $p$ : overbelief is permissible;

$q$ : there are evidentially undecidable irreducibly doxastic genuine options

(such as the option for or against Christian faith).

We claim to have shown by the Jamesian argument: if $q$ then $p$.

But are we to argue by modus ponens: $q$, if $q$ then $p$, therefore $p$, or by modus tollens: not- $p$, if $q$ then $p$, therefore not $-q$ ?

19. See Hilary Putnam Mind, Language and Reality (Cambridge: Cambridge University Press, 1975), 48-49. I am indebted to Gürol Irzik for drawing my attention to Putnam's use of the term 'framework principle'.

20. Another of Putnam's examples, ibid.

21. Wittgenstein's notion of a 'hinge' proposition may apply to framework principles presupposed by such all-pervasive frameworks. Cf. 'the questions that we raise and our doubts depend upon the fact that some propositions are exempt from doubt, as it were like hinges on which those turn'; L. Wittgenstein On Certainty G. E. M. Anscombe and G. H. von Wright (eds), transl. Denis Paul and G. E. M. Anscombe (Oxford: Blackwell, 1969), section 341. I am indebted to Yuri Cath and Jacob Busch for drawing my attention to recent work by Duncan Pritchard on Wittgenstein's notion of a hinge proposition and its potential significance for the epistemology of religious belief (see 'Is "God exists" a "hinge proposition” of religious belief?', International Journal for Philosophy of Religion, 47 (2000), 129-140.

22. Indeed, it may be argued in general that when the regress of nested frameworks stops (as it must), we come to framework principles such that all assessment of evidence presupposes them, yet (pace the rationalist foundationalist project) they are not (all) rationally self-evident.

23. We seem, as a species, to be designed by God (or evolved-as-if-designed through natural processes) so that (when properly functioning) we have so strong a natural inclination to hold true certain fundamental framework principles that we cannot help but accept these truths in our thought and practice. Philosophical reflection uncovers the fact that our attachment to these principles is unsupported by (internal) rational assessment of evidence, but goes too far if it tempts us to dogmatically sceptical conclusions. The correct conclusion may, rather, be that to be a properly functioning human is to be 'programmed' to take what count (from a certain epistemic perspective, anyway) as cognitive risks - risks which evidently have paid off and may be relied on to continue to do so.

24. One philosopher who has provided such extended argument is William Alston in his Perceiving God (Ithaca NY: Cornell University Press, 1991). Indeed, Alston holds that 'it is impossible to give an effective noncircular demonstration of the reliability of any of our basic modes of belief formation', and, hence, that 'the fact that we cannot do this for religious experience is no special demerit of that source of belief'; William Alston The Reliability of Sense Perception (Ithaca NY: Cornell University Press, 1993), ix. In this latter work Alston gives an extended defence of this claim with respect to our formation of beliefs on the basis of sense perception.

25. Of course, this is not to say that such reductive accounts will never be appropriate: commitment to the inductive principle, for example, might be best understood as commitment to follow a certain rule, rather than as the acceptance (whether believing- or otherwise) of a truth claim (about the uniformity of nature, for instance).

26. 'Are our moral preferences true or false, or are they only odd biological phenomena, making things good or bad for $u s$, but in themselves indifferent? How can your pure intellect decide? If your heart does not want a world of moral reality, your head will assuredly never make you believe in one.'; James 'The will to believe', 23. These remarks show that James did not confine permissible overbelief to the religious case, and that his view is at least consonant with my proposal that it is the acceptance of certain framework principles that is the proper sphere for doxastic venture.

27. I am grateful for helpful conversations and critical comment on earlier drafts of this paper to David Braddon-Mitchell, Yuri Cath, Jay Garfield, Richard Holton, Rae Langton, John Llewelyn, Peter Milne, Timothy Sprigge, Timothy Williamson, and two referees for this journal - as also to audiences at the 2001 annual conference of the Australasian Association of Philosophy (Hobart, Tasmania), and at seminars at the University of Auckland, the University of Edinburgh, and the University of Uppsala. 